\title{
Renal dysplasia
}

\author{
R. A. RISDON \\ From the Department of Morbid Anatomy, The Hospital for Sick Children, Great Ormond Street, \\ London
}

\section{Part I A clinico-pathological study of 76 cases}

SYNOPSIS The clinical and pathological findings in 150 children submitted to partial or total nephrectomy have been reviewed. Histological examination of the kidney removed at operation showed evidence of renal dysplasia in $76(51 \%)$. These 76 patients were divided into three main groups on the basis of the pathological changes found in the kidney and the associated urinary tract anomalies. In group 1 , gross cystic renal dysplasia was associated with absence or atresia of the renal pelvis and ureter. In group 2, renal dysplasia was segmental; the ureter, although patent, had some anatomical or functional abnormality which resulted in urinary stasis or reflux. In many of these patients dysplasia was confined to the upper pole of a 'duplex' kidney which was drained by an ectopic ureterocele. In group 3, renal dysplasia was associated with obstruction of the lower urinary tract, most commonly by posterior urethral valves. In group 1 dysplasia was total, involving the whole kidney, whilst in groups 2 and 3 dysplasia tended to be segmental; in the majority some normal renal tissue was present. Pyelonephritis was a very common complication, but was present only in patients from groups 2 and 3 , in whom a lumen was present in the draining ureter, and not in patients from group 1 in whom the ureter was atretic or absent, and the kidney not functioning. It appears that urinary obstruction, stasis, or reflux are the principal factors predisposing to and promoting pyelonephritis in dysplastic kidneys. There seems to be no reason to suppose that dysplastic renal tissue is abnormally susceptible to infection since pyelonephritic changes were lacking in those cases in which dysplasia was most severe.

Renal dysplasia is the abnormal, disorganized development of renal parenchyma due to anomalous differentiation of metanephric tissue. Histologically the normal renal architecture is distorted; the glomeruli, tubules, and collecting ducts are deficient in number, appear morphologically immature, and often undergo cystic changes (Kissane, 1966). The extent of the abnormality varies from a grossly disorganized multicystic dysplasia involving the whole kidney to a less severe segmental change in which part of the kidney is unaffected. Osathanondh and Potter (1964), in a study of the pathogenesis of polycystic kidneys based on microdissection, concluded that cystic dysplasia was due to Received for publication 14 May 1970. diminished branching of the ampullary portion of collecting ducts derived from the ureteric bud, with resulting cyst formation and failure to induce normal nephron formation in the metanephric blastema. The cause of inhibition of ampullary activity in these cases is unknown, but it has been suggested that the frequent association of urinary tract obstruction may be an important factor (Bernstein, 1968). The present study was undertaken in order to assess the frequency of renal dysplasia in kidneys surgically resected in children and to correlate the clinical and pathological changes found. Pyelonephritis complicating renal dysplasia was found to be confined to those cases in which the lumen of the draining. ureter was patent. 


\section{Patients}

The pathological material has been reviewed from 150 consecutive cases of children submitted to total or partial nephrectomy at the Hospital for Sick Children between 1962 and 1969. The case records of these children were also examined in order to correlate the clinical and histopathological findings. Seventy-three were boys and 77 girls, ranging in age between 1 week and 12 years 6 months at the time of operation. The kidney tissue removed was fixed in buffered formalin ( $p H$ 7.0) and between one and five blocks of tissue from each specimen were embedded in paraffin wax. Sections of $5 \mu$ thickness were cut and stained routinely by Ehrlich's haemotoxylin and eosin (H \& E) and, in the majority of cases, by van Gieson's mixture. Other stains were also used when necessary.

The patients fell into six categories (Table I). The main clinical findings and pathological abnormalities, particularly the associated anomalies found in the ureters and lower urinary tracts, are shown. 'Hypoplastic' kidneys were congenitally small; the five examples examined all weighed less than $9 \mathrm{~g}$. Gross multicystic kidneys were those in which the kidney consisted of a disorderly non-reniform mass of cysts of varying size, in which no normal renal parenchyma was recognizable. Partially cystic kidneys were those in which the structural disorganization and cystic change was somewhat less marked and in which some renal parenchyma was present.

\section{Assessment of the Histological Changes}

In each case the histological sections were examined for evidence of renal dysplasia and pyelonephritis.

RENAL DYSPLASIA

The histological diagnosis of renal dysplasia

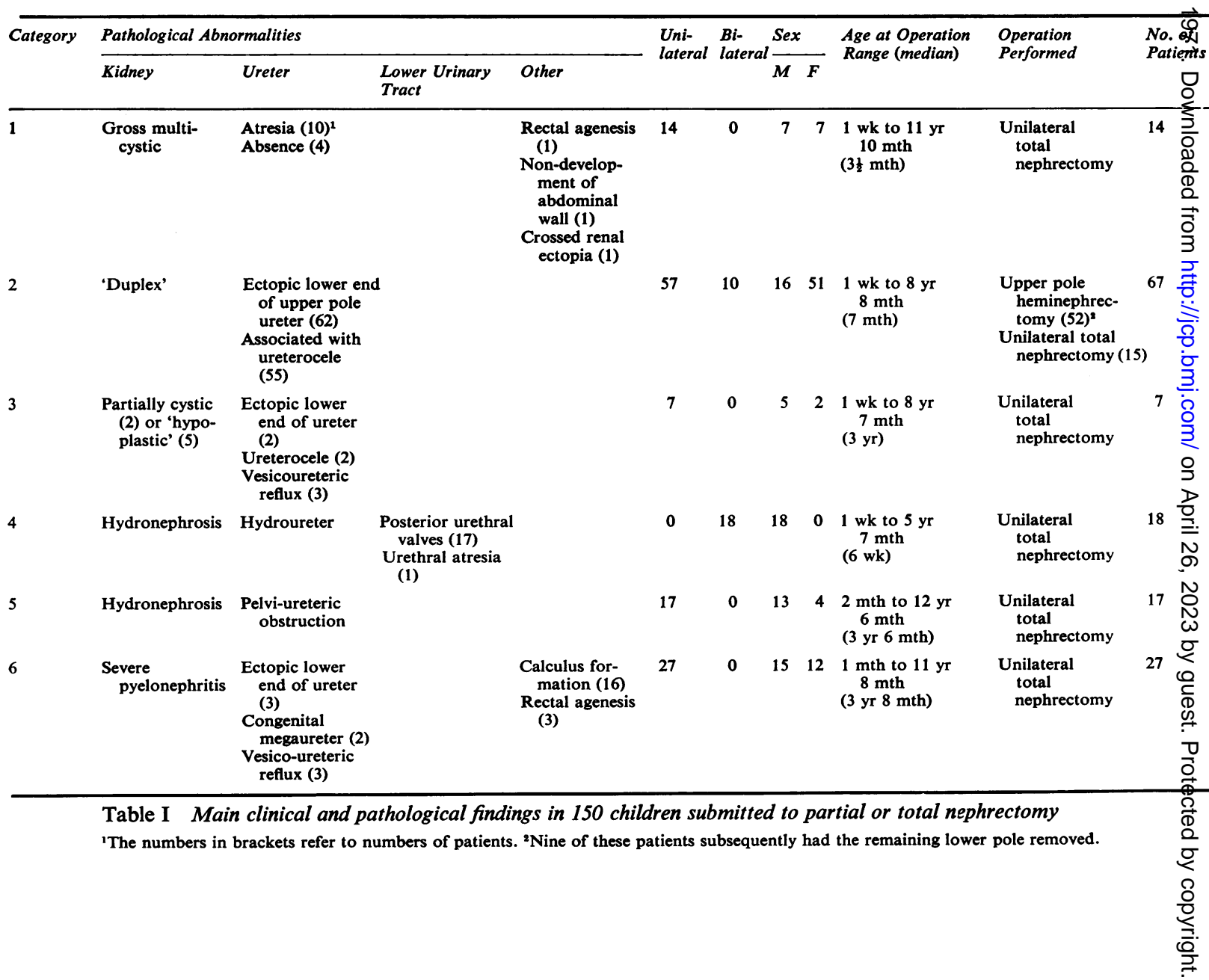


depended primarily upon disorganization of the renal parenchyma, and the presence of 'primitive' ducts. These structures are lined by columnar epithelium and surrounded by concentric mantles of cellular mesenchyme (Fig. 1). They are thought to be derived from the branches of the ureteric bud (Ericsson and Ivemark, 1958a). Often they are aggregated, forming nodular collections (Fig. 2). A case was classified as dysplastic only when these features were present. Foci of metaplastic cartilage (Fig. 3) were also regarded as definite evidence of renal dysplasia, but these were present in only a proportion of the cases showing parenchymal disorganization and 'primitive' ducts. Other so-called 'dysplastic' structures sought were 'foetal' glomeruli (Pasternack, 1960), 'primitive' tubules and ductules (Ericsson and Ivemark, 1958a), and tubular and glomerular cysts (Rubenstein, Meyer, and Bernstein, 1961). These are illustrated in Figures 4 and 5 .

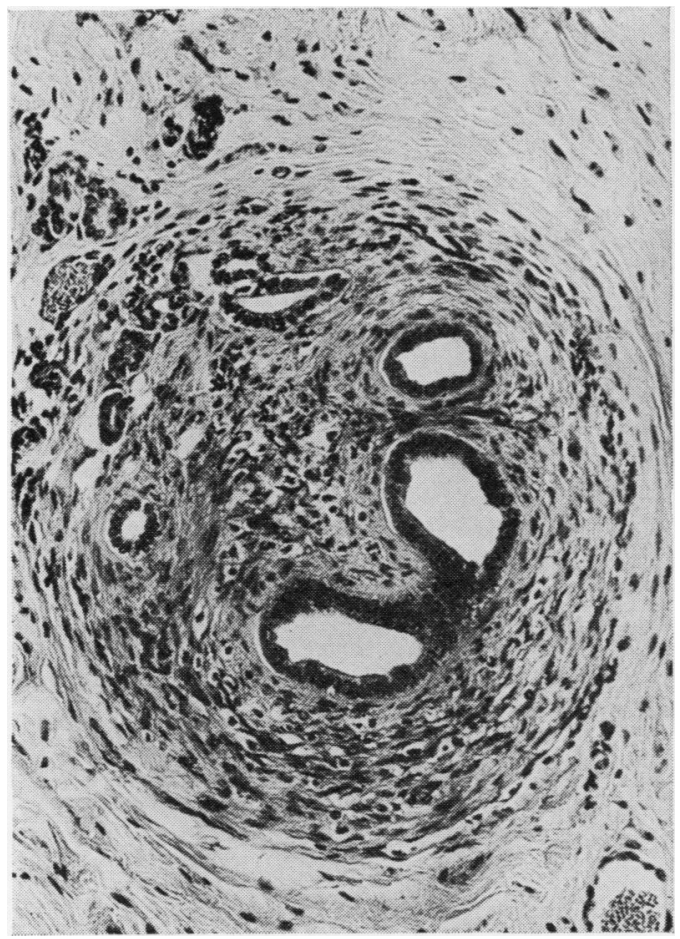

Fig. 1 Renal dysplasia. A 'primitive' duct lined by columnar epithelium and surrounded by concentric rings of mesenchymal cells. $H$. \& E. $\times 20$.
PYELONEPHRITIS

Histological evidence of pyelonephritis sought was the presence of conspicuous acute or chronic inflammation of the renal interstitial tissues and of the mucosa lining the renal pelvis (Figs. 6 and 7). Periglomerular fibrosis, glomerular sclerosis, and foci of tubular atrophy (Fig. 8) were almost invariably present in the inflamed areas.

\section{Results}

These are summarized in Tables II, III, and IV and in Figure 10.

Histological evidence of renal dysplasia was present in $76(51 \%)$ of the 150 patients studied (Table II). These 76 patients were divided into three main groups (Table III) on the basis of the pathological changes found in the kidneys and the associated anomalies in the urinary tract.

Pyelonephritis was a common complication in the cases with renal dysplasia; histological

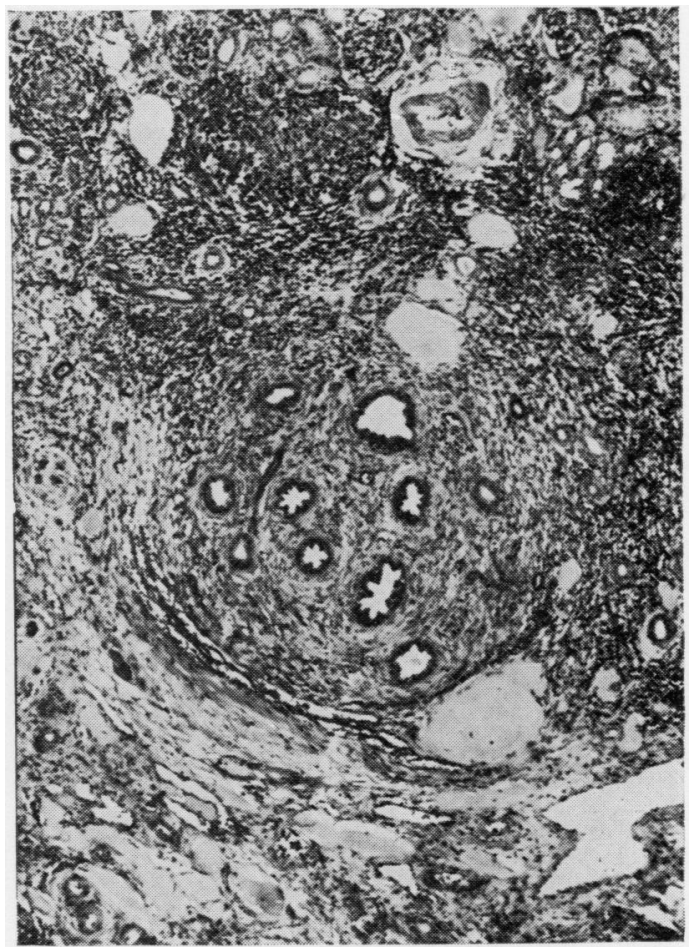

Fig. 2 Renal dysplasia. A group of 'primitive' ducts aggregated to form a nodular collection. $H . \& E . \times$ 10. 


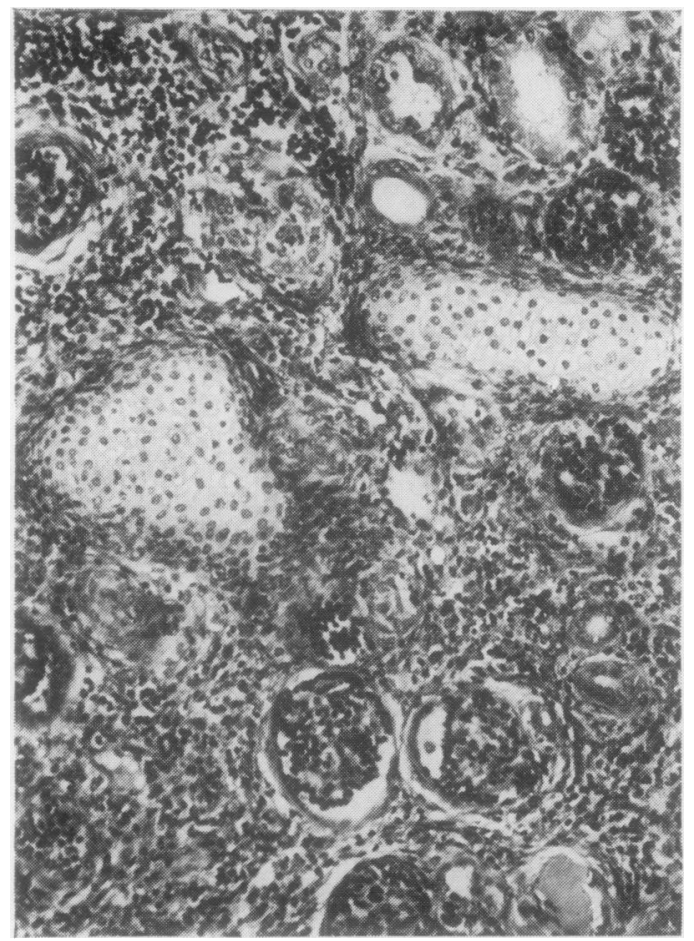

Fig. 3.

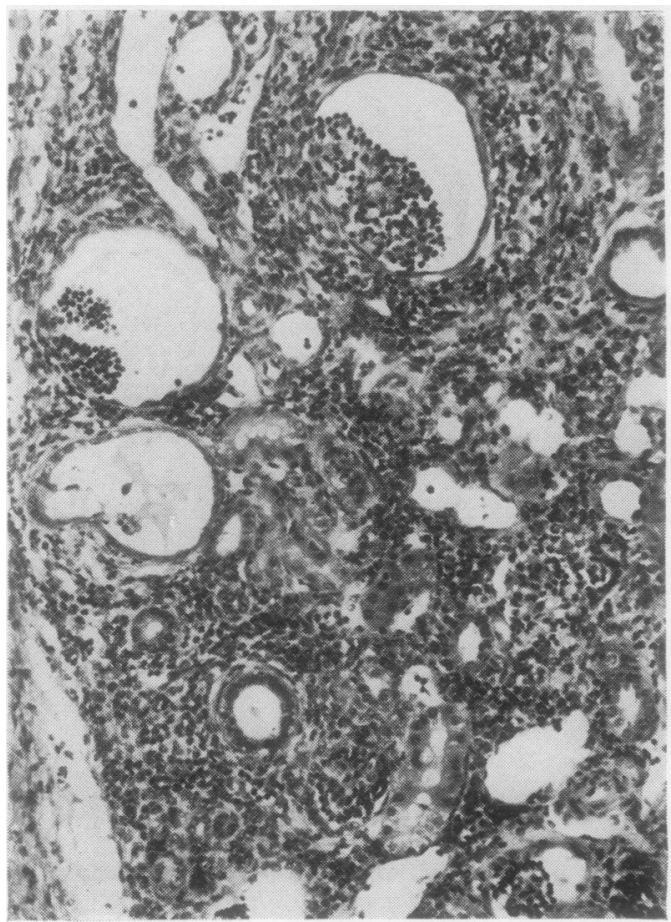

Fig. 4.

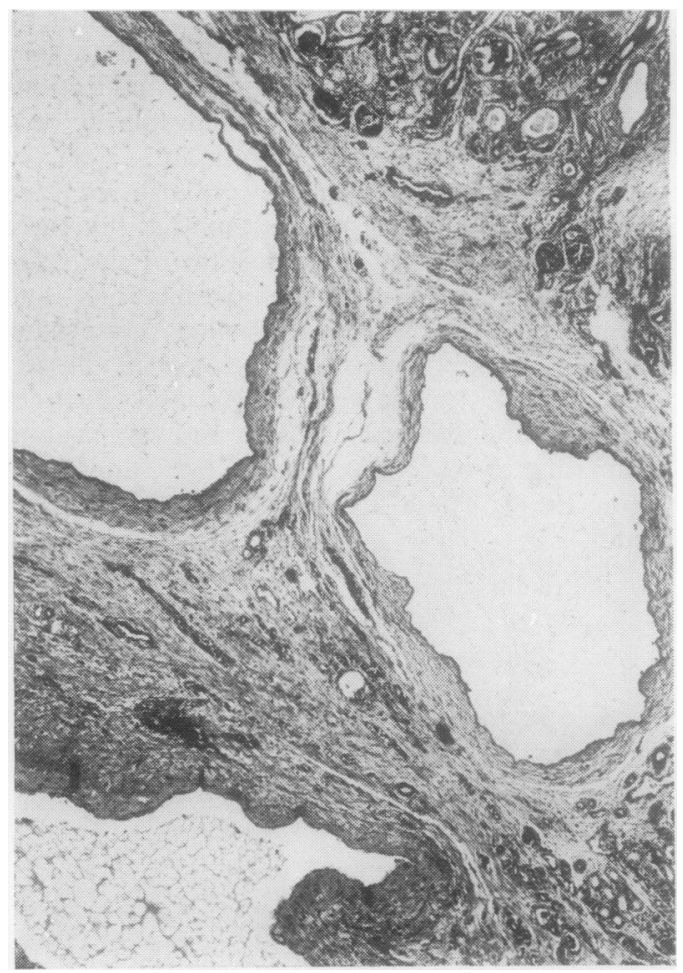

Fig. 5.

Fig. 3 Renal dysplasia. Bars of metaplastic cartilage and 'foetal' glomeruli. H. \& E. $\times 40$.

Fig. 4 Renal dysplasia. 'Primitive' tubules and ductules and glomeruli. Glomerular cysts are also present. H. \& E. $\times 20$.

Fig. 5 Renal dysplasia. Large fibrous-walled cysts. H. \& E. $\times 10$. 


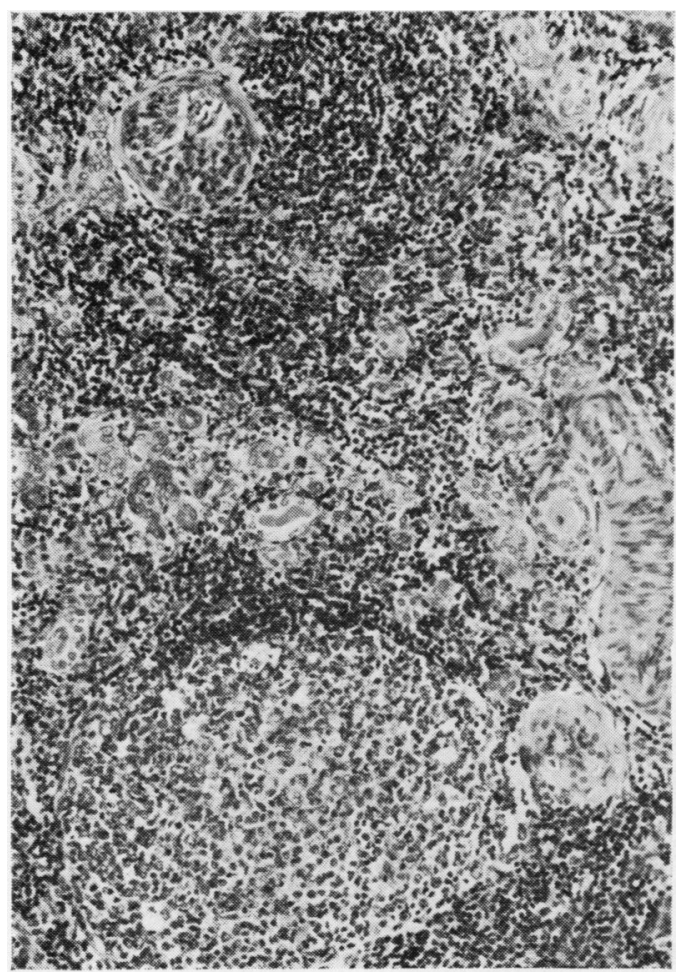

Fig. 6.

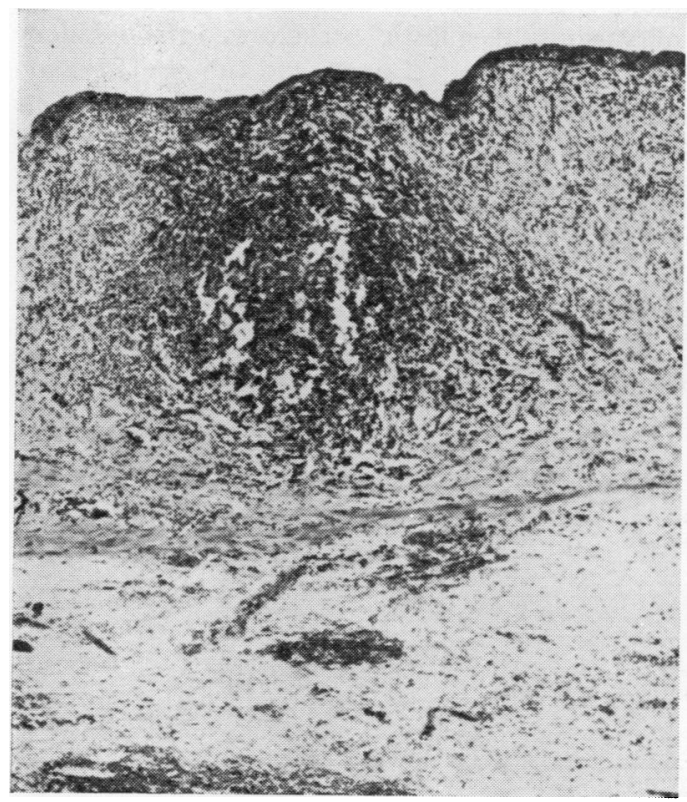

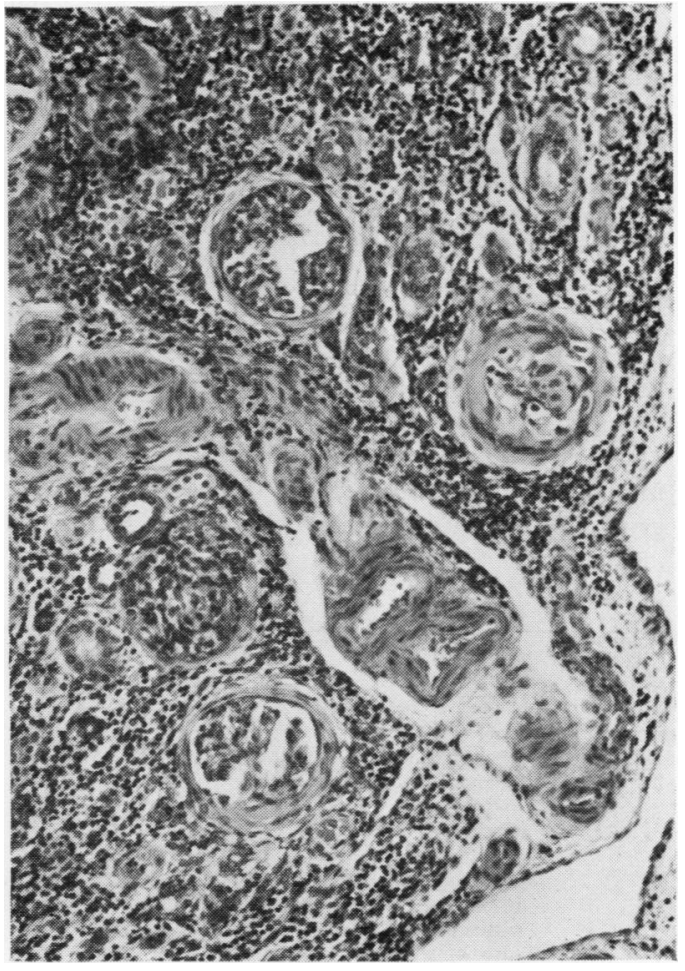

Fig. 8.

Fig. 6 Pyelonephritis. Marked interstitial chronic inflammation with lymphoid follicle formation. H. \& E. $\times 40$.

Fig. 7 Pyelonephritis. Chronic inflammation of the renal pelvis. H. \& E. $\times 10$.

Fig. 8 Pyelonephritis. Periglomerular fibrosis and glomerular sclerosis in an area of chronic inflammation. H. \& E. $\times 40$. 
evidence of this condition was present in 58 $(76 \%)$, but was found only in patients in groups 2 and 3 (Table IV). Two patients in group 1 had clinical evidence of urinary tract infection (pyuria and bacteriuria) but in both the opposite kidney was abnormal; in one intravenous pyelography showed a small kidney with clubbed calyces, and in the other hydronephrosis due to stenosis of the pelvi-ureteric junction was found.

The blood urea concentration, which in each case was measured a few days before operation, was often raised in all three groups (Fig. 9). In group 1 the urea concentration was normal or moderately raised in all but two cases in which the levels were more markedly raised (141 and $153 \mathrm{mg} / 100 \mathrm{ml})$. In these instances there were marked abnormalities in the opposite kidney. In group 2, one case had a urea level of $150 \mathrm{mg} / 100$

\begin{tabular}{lllc}
\hline $\begin{array}{l}\text { Patient } \\
\text { Category }\end{array}$ & $\begin{array}{l}\text { Main Pathological } \\
\text { Abnormalities }\end{array}$ & $\begin{array}{l}\text { No. with } \\
\text { Renal } \\
\text { Dysplasia }\end{array}$ & $\begin{array}{l}\text { Total No. } \\
\text { of Patients }\end{array}$ \\
\hline 1 & $\begin{array}{l}\text { Gross multicystic dysplasia } \\
\text { 'Duplex' kidney with double } \\
\text { ureters }\end{array}$ & 14 & 14 \\
3 & $\begin{array}{l}\text { Partially cystic or } \\
\text { 'hypoplastic' kidney } \\
\text { Hydronephrosis due to } \\
\text { lower urinary tract } \\
\text { obstruction }\end{array}$ & 78 & 67 \\
4 & $\begin{array}{l}\text { Hydronephrosis due to } \\
\text { pelvi-ureteric stenosis }\end{array}$ & 0 & 7 \\
5 & $\begin{array}{l}\text { Severe pyelonephritis } \\
\text { Total }\end{array}$ & 0 & 17 \\
6 & 76 & 150 \\
\hline
\end{tabular}

Table II Number of patients in each category showing histological evidence of renal dysplasia

\begin{tabular}{lcc}
\hline Renal Dysplasia & $\begin{array}{l}\text { Pyurial and } \\
\text { Bacteriuria }\end{array}$ & $\begin{array}{l}\text { Histological Evidence } \\
\text { of Pyelonephritis }\end{array}$ \\
\hline Group 1 (14 cases) & 2 & 0 \\
Group 2 (45 cases) & 31 & 44 \\
Group 3 (17 cases) & 13 & 14 \\
\hline
\end{tabular}

Table IV Incidence of pyelonephritis in the three groups of patients with renal dysplasia

ml. This child died two days after operation. In the remainder the initial urea level was often raised, but in every case fell to less than 35 $\mathrm{mg} / 100 \mathrm{ml}$ following operation. In group 3 the blood urea was usually raised and was less than $40 \mathrm{mg} / 100 \mathrm{ml}$ in only six cases.

Mortality was highest amongst patients in group 3, five of whom died of renal failure between three weeks and 30 months after operation. In group 1 , one patient died of renal failure. This child had severe hydronephrosis of the contralateral kidney due to stenosis of the pelvi-ureteric junction. In group 2, one child died in the postoperative period. He had severe bilateral hydronephrosis due to an obstructing ectopic ureterocele in the urinary bladder.

\section{Discussion}

The criteria on which the histological identification of renal dysplasia is based are unsatisfactory. The diagnosis depends on the recognition of various 'dysplastic' structures in the kidney including 'primitive' ducts and tubules (Ericsson and Ivemark, 1958a), metaplastic cartilage

\begin{tabular}{|c|c|c|c|c|c|c|c|c|c|c|c|}
\hline \multirow[t]{2}{*}{ Group } & \multicolumn{2}{|c|}{ Pathological Abnormalities } & \multicolumn{2}{|c|}{$\operatorname{Sex}$} & \multirow{2}{*}{$\begin{array}{l}\text { Age at Operation } \\
\text { Range (median) }\end{array}$} & \multicolumn{2}{|c|}{ Nephrectomy } & \multicolumn{2}{|l|}{ Side } & \multirow{2}{*}{$\begin{array}{l}\text { Follow up (mth) } \\
\text { Range (mean) } \\
\text { No. of Cases }\end{array}$} & \multirow{2}{*}{$\begin{array}{l}\text { Total No } \\
\text { of } \\
\text { Patients }\end{array}$} \\
\hline & Kidney & $\begin{array}{l}\text { Ureter and Lower } \\
\text { Urinary Tract }\end{array}$ & $M$ & $\boldsymbol{F}$ & & Total & Partial & $\boldsymbol{R}$ & $L$ & & \\
\hline 1 & Gross multicystic & $\begin{array}{l}\text { Atresia of ureter (10) } \\
\text { Absence of ureter (4) }\end{array}$ & 7 & 7 & $\begin{array}{l}1 \text { wk to } 11 \text { yr } 10 \\
\text { mth } \\
\left(3 \frac{1}{2} \mathrm{mth}\right)\end{array}$ & 14 & $\mathbf{0}$ & 5 & 9 & $\begin{array}{c}2 \text { to } 60 \\
(20) \\
13 \text { cases }\end{array}$ & 14 \\
\hline \multirow[t]{2}{*}{2} & 'Duplex' (38)' & $\begin{array}{c}\text { Ectopic insertion of } \\
\text { upper pole ureter } \\
(38) \\
\text { Ectopic ureterocele }\end{array}$ & & & & & & & & & \\
\hline & $\begin{array}{l}\text { 'Hypoplastic or } \\
\text { partially cystic (7) }\end{array}$ & $\left.\begin{array}{l}\text { (36) } \\
\text { Ectopic insertion of } \\
\text { ureter (2) } \\
\text { Ureterocele (2) } \\
\text { Vesico-ureteric } \\
\text { reflux (3) }\end{array}\right\}$ & 13 & 32 & $\begin{array}{l}1 \text { wk to } 8 \text { yr } 8 \mathrm{mth} \\
\text { (9 mth) }\end{array}$ & 16 & $\begin{array}{l}30 \\
1 \\
\text { (bilat) }\end{array}$ & $\begin{array}{l}29 \\
1 \\
\text { (bilat }\end{array}$ & 17 & $\begin{array}{l}30 \text { to } 140 \\
(38) \\
41 \text { cases }\end{array}$ & 45 \\
\hline 3 & Hydronephrosis & $\begin{array}{l}\text { Hydroureter (17) } \\
\text { Posterior urethral } \\
\text { valves (16) } \\
\text { Urethral atresia (1) }\end{array}$ & 17 & 0 & $\begin{array}{l}1 \text { wk to } 5 \text { yr } 7 \mathrm{mth} \\
\text { (6 wk) }\end{array}$ & 17 & $\mathbf{0}$ & 9 & 8 & $\begin{array}{c}1 \text { to } 82 \\
(28) \\
17 \text { cases }\end{array}$ & 17 \\
\hline
\end{tabular}

Table III Main pathological findings in patients with renal dysplasia

${ }^{1}$ The numbers in brackets refer to numbers of patients. 


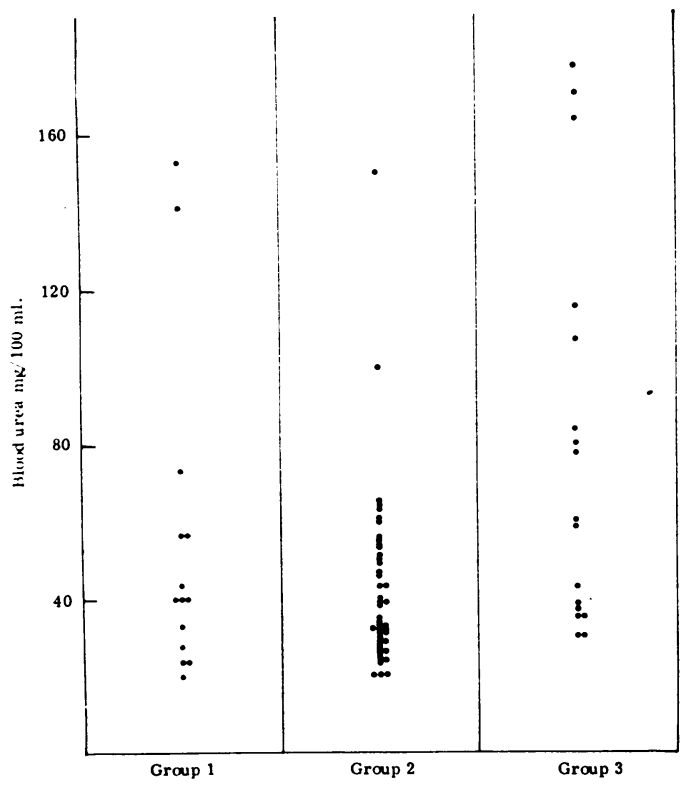

Fig. 9 Blood urea estimations immediately before operation in the three groups of patients with renal dysplasia.

(Bigler and Killingsworth, 1949), 'foetal' glomeruli (Pasternack, 1960), and renal cysts (Rubenstein et al, 1961). However, Bernstein (1968) has demonstrated in the kidneys of young children that an apparently 'primitive' morphology may be induced in glomeruli, tubules, and ductules as a result of ischaemic damage, or even by scarring following renal biopsy, without there being any suggestion of maldevelopment. For these reasons, in the present study, the histological diagnosis was based on the presence of structural disorganization of the renal parenchyma as a result of abnormal development, and on the presence of 'primitive' ducts of the type described by Ericsson and Ivemark. These structures are thought to represent branches of the ureteric bud, and are not seen in conditions other than renal dysplasia (Bernstein, 1968). Bars of metaplastic cartilage have also been regarded as definite evidence of renal dysplasia (Bigler and Killingsworth, 1949), but since they are not always present even in obviously dysplastic kidneys, their presence was regarded more as useful confirmation of the diagnosis. Dysplastic changes may sometimes be confused with those due to hydronephrosis, particularly when the two con-

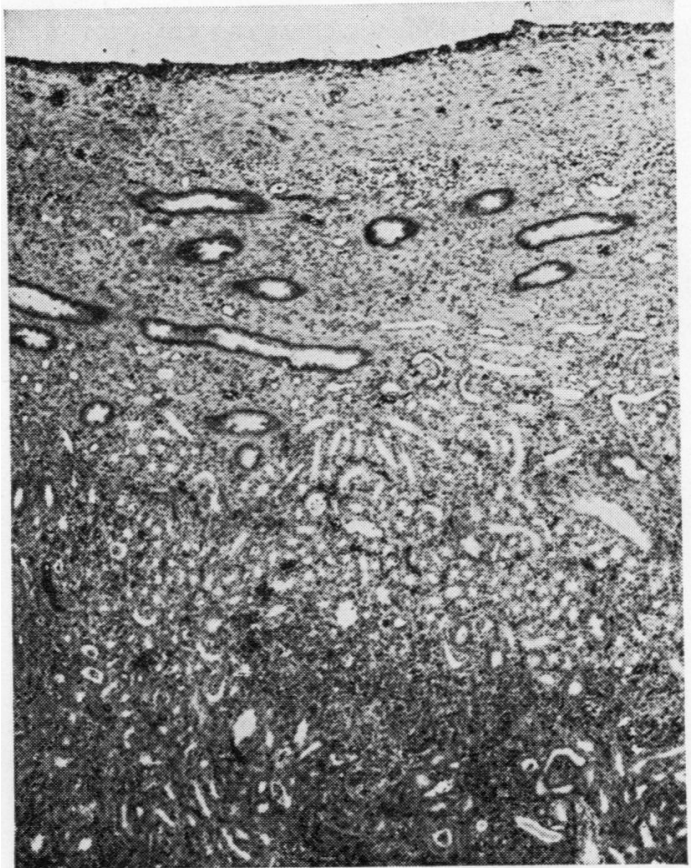

Fig. 10 Hydronephrosis. Flattening of the renal papilla and atrophy of the medulla. The collecting ducts are separated by fibrous connective tissue. H. \& E. $\times 10$.

ditions coexist. Flattening of the renal papillae as a result of back pressure causes a tangential rather than a radial alignment of the collecting ducts. The ducts become separated by fibrous connective tissue which may condense around the tubules and mimic mantles of mesenchyme (Fig. 10). Such cases may account for descriptions of so-called pure medullary dysplasia (Gwinn and Landing, 1968). In the cases studied it was usually evident that hydronephrosis primarily produced atrophic changes in the medulla, the cortex becoming thin only at a late stage. In renal dysplasia the cortex was disorganized and usually markedly thinned by comparison with the adjacent medulla. 'Primitive' ducts were often aggregated together and formed nodules (Fig. 2), a feature not seen in pure hydronephrosis.

In the present series, histological evidence of renal dysplasia was found in $51 \%$ of cases. Consideration of the pathological changes in the kidneys and the associated urinary tract abnormalities allowed their division into three groups (Table III). In group 2 cases of 'duplex' kidney with double ureters were included with cases in which the kidneys were 'hypoplastic' or partially cystic. This was considered reasonable, 
since in all the dysplastic changes were segmental, and in all the ureter draining the dysplastic kidney, whilst possessing a lumen, showed some structural or functional abnormality which resulted in urinary stasis or reflux.

Elevation of the blood urea concentration was seen in a proportion of patients from all three groups, but was most common in those in group 3 with obstruction of the lower urinary tract. In fact, in most cases in group 3 the initial blood urea level had been higher, but the establishment of bilateral ureterostomies or nephrostomies produced a fall in the blood urea. Nephrectomies were performed when urine formation was so slight as to suggest little useful renal function. In all cases in group 2 with raised blood urea concentrations, ectopic ureteroceles (Berdon, Baker, Becker, and Uson, 1968) were present in the urinary bladder. The fact that urea levels fell after operation suggests that the initial elevation may have been due to urinary obstruction by the ureterocele. In group 1, the blood urea levels were markedly raised in two cases in which abnormalities were also present in the contralateral kidney and moderately raised (57 and $74 \mathrm{mg} \%$ ) in two others. Both of these were young infants, less than 2 weeks old. The raised blood urea level in these cases may reflect a relative inability of the opposite 'normal' kidney to cope as a result of some functional immaturity.

The mortality was highest in patients in group 3 , five of whom died of renal failure. This was not surprising since they all presented with bilateral hydronephrosis and hydroureters and the resulting renal damage was sufficient to destroy entirely the function in at least one kidney.

Pyelonephritis was a very common complication in those patients with renal dysplasia. Histological evidence of pyelonephritis was found in $76 \%$ of the cases. This association has also been emphasized by others (Marshall, 1953; Ericsson and Ivemark, 1958b; Pasternack, 1960). These authors concluded that dysplastic renal tissue was abnormally susceptible to infection in much the same way as areas of scar tissue in the kidney (Rocha, Guze, Freedman, and Beeson, 1958). Marshall (1968) even suggested that most cases of pyelonephritis in the adult arise from infection of areas of renal dysplasia. In the present study, although pyelonephritis was common, it occurred only in patients in groups 2 and 3 in whom a lumen was present in the draining ureter, and not in group 1 in whom the ureter was absent or atretic, and the kidney was not functioning. Two patients in group 1 had clinical evidence of a urinary tract infection, but in both there were marked abnormalities of the opposite kidney. Such a finding is not uncommon in cases of cystic renal dysplasia (Pathak and Williams, 1964). In both these cases histological evidence of pyelonephritis was lacking in the resected dysplastic kidney. In any case, pyuria and bacteruria in the voided urine could hardly have arisen in this kidney since it was effectively isolated by an atretic ureter.

It appears that a lumen is necessary in the draining ureter for infecting organisms to gain access to the dysplastic kidney. Structural or functional abnormalities in the ureter or lower urinary tract causing urinary stasis or reflux seem to be the most important factors in promoting pyelonephritis in dysplastic kidneys as in other situations. There is no reason to conclude that dysplastic renal tissue is abnormally prone to infection since pyelonephritis was absent in those cases in group 1 in which dysplasia was most widespread and severe. Absence or atresia of ureter in these cases may be a secondary phenomenon. Dysplasia was marked and affected the whole kidney and it seems unlikely that urine formation could have occurred at any stage in its development. It is possible that the maintenance of a lumen in the developing ureter requires the passage of urine and in its absence the lumen either does not develop or even the ureter may disappear.

\section{References}

Berdon, W. E., Baker, D. H., Becker, J. A., and Uson, A. C. (1968). Ectopic ureterocele. Radiol. Clin. N. Amer., 6, 205-214.

Bernstein, J. (1968). Developmental abnormalities of the renal parenchyma-renal hypoplasia and dysplasia. Path. Ann., 3, 213-247.

Bigler, J. A., and Killingsworth, W. P. (1949). Cartilage in the kidney. Arch. Path., 47, 487-493.

Ericsson, N. O., and Ivemark, B. I. (1958a). Renal dysplasia and pyelonephritis in infants and children. Part I. Arch. Path., 66, 255-263.

Ericsson, N. O., and Ivemark, B. I. (1958b). Renal dysplasia and pyelonephritis in infants and children. Part II. Primitive ductules and abnormal glomeruli. Arch. Path., 66, 264-269.

Gwinn, J. L. and Landing, B. H. (1968). Cystic diseases of the kidneys in infants and children. Radiol. Clin. N. Amer., 6, 191-204.

Kissane, J. M. (1966). Congenital malformations. In Pathology of the Kidney by R. H. Heptinstall, pp. 63-117. Churchill, London.

Marshall, A. G. (1953). Persistence of foetal structures in pyelonephritic kidneys. Brit. J. Surg., 41, 38-50.

Marshall, A. G. (1968). Scars of the infant renal cortex. J. Path. Bact., 95, 225-231.

Osathanondh, V., and Potter, E. L. (1964). Pathogenesis of polycystic kidneys type 2 due to inhibition of ampullary activity. Arch. Path., 77, 474-484.

Pasternack, A. (1960). Microscopic structural changes in macroscopically normal and pyelonephritic kidneys of children. Ann paediat. Fenn., 6, Suppl. 14.

Pathak, I. G., and Williams, D. I. (1964). Multicystic and cystic dysplastic kidneys. Brit. J. Uroi., 36, 318-331. 
Rocha, H., Guze, L. B., Freedman, L. R., and Beeson, P. B. (1958). Experimental pyelonephritis. III. The influence of localized injury in different parts of the kidney on susceptibility to bacillary infection. Yale. J. Biol. Med., 30, 341-354.
Rubenstein, M., Meyer, R., and Bernstein, J. (1961). Congenital abnormalities of the urinary system. I. A postmortem survey of developmental anomalies and acquired congenital lesions in a children's hospital. J. Pediat., 58, 356-366.

\section{Part II A necropsy study of 41 cases}

SYNOPSIS The pathological findings at necropsy have been reviewed in 121 children with congenital malformations of the kidney and lower urinary tract. Histological examination of the kidneys revealed evidence of renal dysplasia in $41(34 \%)$. Comparison of these 41 cases with other cases in which renal dysplasia was found in kidneys removed surgically showed a much higher incidence of bilateral involvement and of other associated major congenital abnormalities. Histological evidence of pyelonephritis was less common except in those cases in which renal dysplasia was associated with lower urinary tract obstruction. A total of 34 children with bilateral hydronephrosis and hydroureters due to congenital urethral obstruction was found, and in these cases severe degrees of renal dysplasia were present only in those dying in the first two months.

Many previous reviews have been made of multicystic and 'hypoplastic' renal dysplasia (Elkstrom, 1955; Spence, 1955; Coppridge and Ratliff, 1958; Parkkulainen, Hjelt, and Sirola, 1959; Vellios and Garrett, 1961) but rather less emphasis has been given to renal dysplasia associated with congenital lower urinary tract obstruction (Pathak and Williams, 1964; Rattner, Meyer, and Bernstein, 1963). For this reason a separate quantitative study was made of the incidence and degree of renal dysplasia present in the 34 children with obstruction of the lower urinary tract included in the present series.

\section{Patients}

A review of the necropsy records at the Hospital for Sick Children for the period between 1954 and 1969 revealed 157 congenital malformations of the kidney and lower urinary tract occurring in 121 children. Eighty-four were boys and 37 girls ranging between 1 day and 13 years 6 months at death. The various anomalies encountered are shown in Table I. In each case histological sections from the kidneys were examined. Blocks of kidney tissue had been fixed in buffered formalin $(p H$ 7.0) and embedded in paraffin wax. Sections were cut of $5 \mu$ and stained routinely by Ehrlich's haematoxylin and eosin (H and E); other stains were employed where necessary.

\section{Assessment of the Histological Changes}

In each case the histological sections were

\begin{tabular}{ll}
\hline Classification & $\begin{array}{l}\text { No. of } \\
\text { Cases }\end{array}$ \\
\hline
\end{tabular}

1 Anomalies of Structure

$\begin{array}{ll}\text { (a) Agenesis } & 15 \\ \text { (b) Polycystic disease } & 10 \\ \text { (c) Simple renal 'hypoplasia' } & 12 \\ \text { (d) Renal dysplasia } & 41\end{array}$

2 Anomalies of Position or Shape
(a) Renal ectopia
(b) Renal fusion
(c) 'Duplex' kidney

3 Anomalies of Lower Urinary Tract
(a) Extrophy of the bladder
(b) Duplication of the bladder
(c) Rectourethral fistula
(d) Megacystic-megaureter without obstruction
(e) Congenital urethral obstruction Total

Table I Classification of 157 congenital abnormalities of the kidneys and lower urinary tract found at necropsy in 121 children 
examined for evidence of renal dysplasia and pyelonephritis using the criteria described previously (Risdon, 1970).

In addition a separate quantitative assessment of the degree of renal dysplasia present in the kidneys from the 34 children with bliateral hydronephrosis and hydroureters due to congenital lower urinary tract obstruction was made as follows: $\mathbf{O}=$ where there was no histological evidence of renal dysplasia. $+=$ where occasional foci of renal dysplasia were seen, but most of the renal parenchyma was normally differentiated (Fig. 1). $++=$ where renal dysplasia was segmental, with areas of normally and anomalously differentiated parenchyma present (Fig. 2). $+++=$ where renal dysplasia was total, but some separation of the renal parenchyma into cortex and medulla was discernible. Cystic changes tended to be prominent in the subcapsular zone (Fig. 3). $++++=$ where dysplasia was total and complete disorganization of the renal parenchyma was associated with marked cystic changes (Fig. 4).

In 33 of the 34 cases sections from both kidneys were examined. In the remaining case, unilateral renal agenesis was present, and a section from the single kidney was examined.

\section{Results}

Histological evidence of renal dysplasia was present in $41(34 \%)$ of the cases studied and was bilateral in just over half of them ( 23 cases).

The 41 children with renal dysplasia were divided into three groups (Table II) on the basis of the pathological changes in the kidney and the associated anomalies in the draining urinary tract as described previously (Risdon, 1970). Dysplasia was bilateral in $23(63 \%)$ and additional congenital abnormalities were frequently present both in the urogenital system and also in other systems, particularly the cardiovascular and gastrointestinal systems. These are summarized in Table III.

Histological evidence of renal infection or pyelonephritis was present in two of nine cases from group 1, three of the 10 cases from group 2, and in 17 of the 22 cases from group 3.

Of the two cases affected in group 1 , in the first, evidence of pyelonephritis was confined to the contralateral non-dysplastic kidney, in which there was hydronephrosis due to mid-ureteric obstruction. In the other case, there was focal abscess formation in the cystic dysplastic kidney and a pyonephrosis in the other kidney due to pelvi-ureteric stenosis. In group 2, the three cases

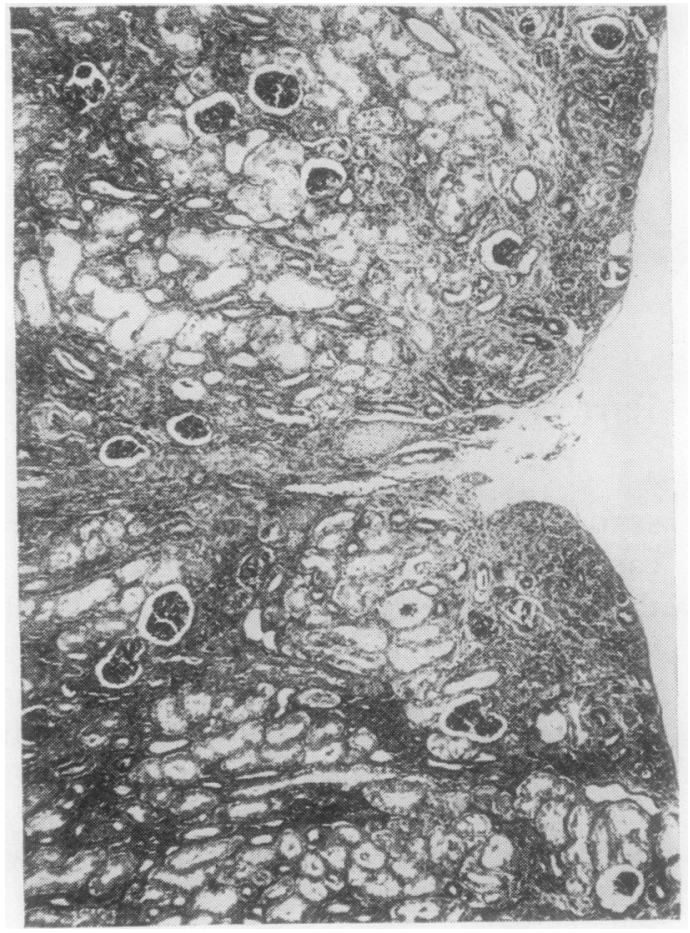

Fig. 1 Renal dysplasia (group 3). Grade + changes. A focal dysplastic area is shown, but most of the renal parenchyma is normally differentiated. $H \& E \times$ 15.

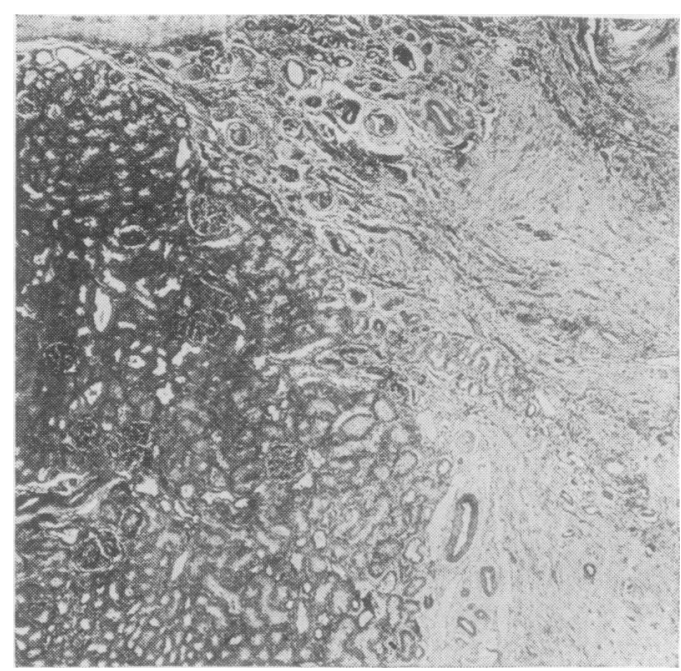

Fig. 2 Renal dysplasia (group 3). Grade ++ changes. Adjacent areas of renal parenchyma, on the left showing normal development and on the right dysplasia. $H \& E \times 10$. 


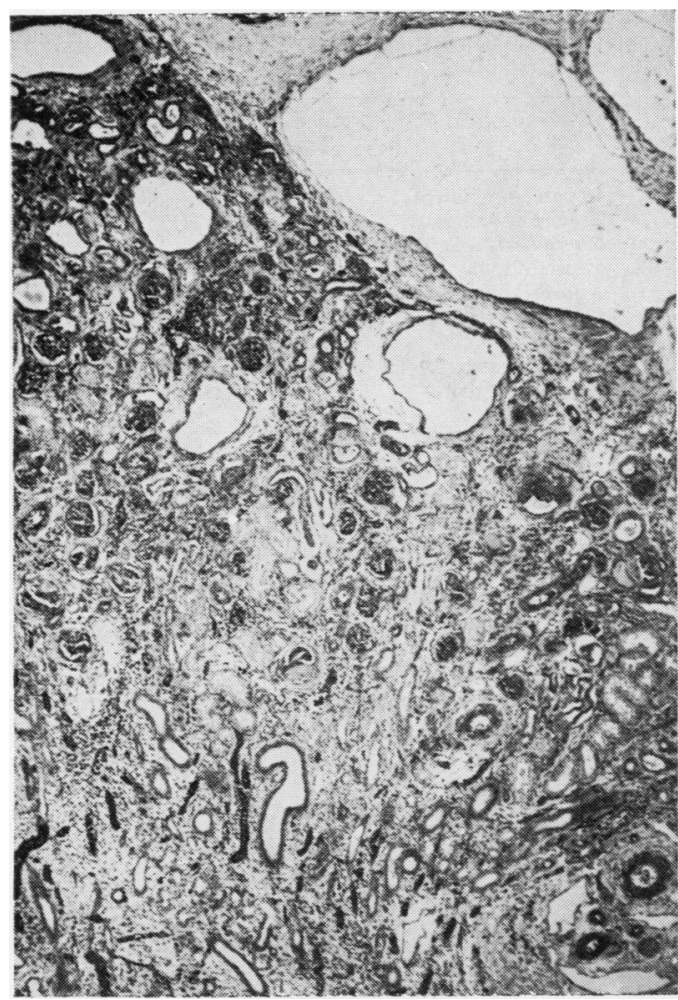

Fig. 3 Renal dysplasia (group 3). Grade +++ changes. Renal dysplasia is total but some differentiation of cortex and medulla is seen. Subcapsular cyst formation is prominent. $H \& E \times 10$.

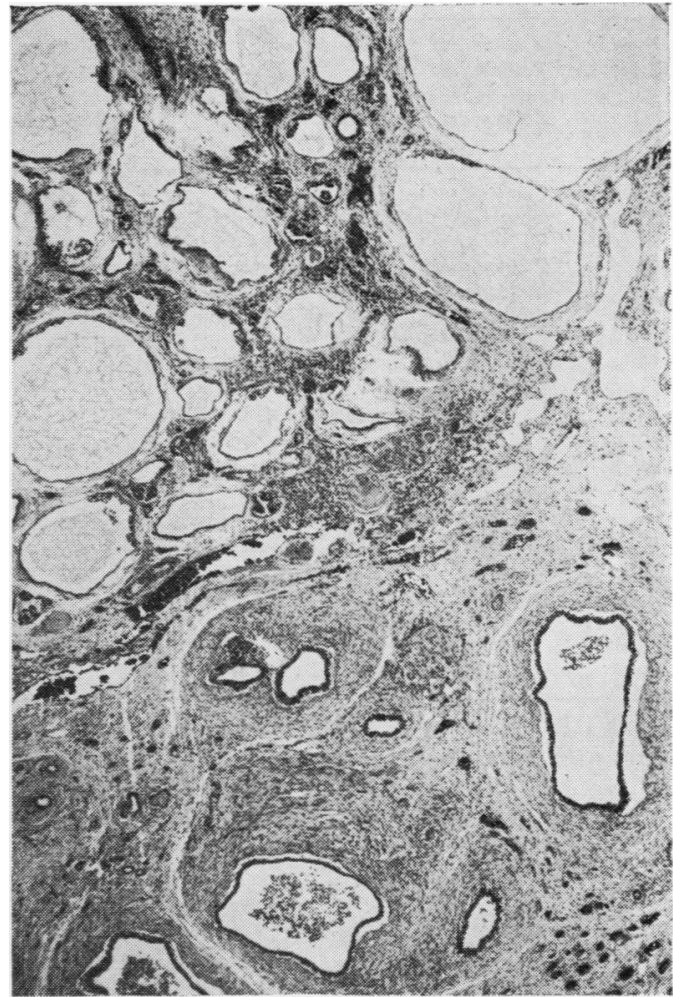

Fig. 4 Renal dysplasia (group 3). Grade ++++ changes. There is complete disorganization of the renal parenchyma and cystic changes are marked. $H \& E \times 10$.

\begin{tabular}{|c|c|c|c|c|c|c|c|}
\hline \multirow[t]{2}{*}{ Dysplasia } & \multirow{2}{*}{$\begin{array}{l}\text { No. of } \\
\text { Patients }\end{array}$} & \multirow{2}{*}{$\begin{array}{l}\text { Unilateral } \\
\text { Involvement }\end{array}$} & \multicolumn{2}{|c|}{ Pathological Abnormalities } & \multirow{2}{*}{$\begin{array}{l}\text { Bilateral } \\
\text { Involvement }\end{array}$} & \multicolumn{2}{|c|}{ Pathological Abnormalities } \\
\hline & & & Kidney & $\begin{array}{l}\text { Ureter and Lower } \\
\text { Urinary Tract }\end{array}$ & & Kidney & $\begin{array}{l}\text { Ureter and Lower } \\
\text { Urinary Tract }\end{array}$ \\
\hline Group 1 & 9 & 6 & $\begin{array}{l}\text { Gross } \\
\text { multicystic }\end{array}$ & $\begin{array}{l}\text { Absence of ureter (1) } \\
\text { Atresia of ureter (3) } \\
\text { Gross narrowing of } \\
\text { ureter (2) }\end{array}$ & 3 & $\begin{array}{l}\text { Gross } \\
\text { multicystic }\end{array}$ & $\begin{array}{l}\text { Bilateral atresia of } \\
\text { ureters (2) } \\
\text { Absence of one ureter } \\
\text { and atresia of contra- } \\
\text { lateral ureter (1) }\end{array}$ \\
\hline Group 2 & $\begin{array}{l}10 \\
\text { (M5; F5) }\end{array}$ & 6 & $\begin{array}{l}\text { 'Duplex' (1) } \\
\text { 'Hypoplastic' or } \\
\text { partially cystic (5) }\end{array}$ & $\begin{array}{l}\text { Ectopic insertion of } \\
\text { upper pole ureter (1) } \\
\text { Ureterocele (1) } \\
\text { Ectopic insertion of } \\
\text { ureter (2) } \\
\text { hydroureter (2) }\end{array}$ & 4 & $\begin{array}{l}\text { 'Hypoplastic' or } \\
\text { partially cystic (4) }\end{array}$ & $\begin{array}{l}\text { Ectopic insertion of } \\
\text { one ureter; the opposite } \\
\text { ureter hypoplastic (1) } \\
\text { Bilateral hypoplastic } \\
\text { ureters (1) } \\
\text { Bilateral hydroureters } \\
\text { (1) }\end{array}$ \\
\hline Group 3 & $\begin{array}{l}22 \\
\text { (M22) }\end{array}$ & $6^{2}$ & $\begin{array}{l}\text { Hydronephrosis } \\
\text { (6) }\end{array}$ & $\begin{array}{l}\text { Hydroureter (6) } \\
\text { Posterior urethral } \\
\text { valves (5) } \\
\text { Urethral stenosis (1) }\end{array}$ & 16 & $\begin{array}{l}\text { Hydronephrosis } \\
\text { (16) }\end{array}$ & $\begin{array}{l}\text { Hydroureters (16) } \\
\text { Posterior urethral } \\
\text { valves (12) } \\
\text { Urethral stenosis (2) } \\
\text { Urethral atresia (1) }\end{array}$ \\
\hline
\end{tabular}

Table II Main pathological findings in kidneys and draining urinary tract in three groups of cases with renal dysplasia.

${ }^{1}$ The numbers in brackets refer to the numbers of patients.

'This figure refers to the incidence of unilateral renal dysplasia. In this group, hydronephrosis was invariably bilateral with the exception of one case where agenesis of one kidney was present. 


\begin{tabular}{|c|c|c|c|c|c|c|}
\hline \multirow[t]{2}{*}{$\begin{array}{l}\text { Renal } \\
\text { Dysplasia }\end{array}$} & \multicolumn{2}{|c|}{$\begin{array}{l}\text { Associated Anomalies in the } \\
\text { Urogenital System }\end{array}$} & \multicolumn{4}{|c|}{ Associated Anomalies in Other Systems } \\
\hline & Kidney and Ureter & Other & Cardiovascular & Gastrointestinal System & $\begin{array}{l}\text { Central Nervous } \\
\text { System }\end{array}$ & $\begin{array}{l}\text { Other } \\
\text { Systems }\end{array}$ \\
\hline $\begin{array}{l}\text { Group } 1 \\
\text { (9 cases) }\end{array}$ & $\begin{array}{l}\text { Contralateral renal } \\
\text { agenesis (1) } \\
\text { Contralateral } \\
\text { hydronephrosis due to } \\
\text { ureteric stenosis (2) } \\
\text { Ectopia of dysplastic } \\
\text { kidney (1) } \\
\text { Renal fusion (1) }\end{array}$ & $\begin{array}{l}\text { Extrophy of } \\
\text { bladder (1) } \\
\text { Rectovesical } \\
\text { fistula (1) } \\
\text { Bicornuate } \\
\text { uterus (1) }\end{array}$ & $\begin{array}{l}\text { Patent ductus } \\
\text { arteriosus (3) } \\
\text { Atrial septal defect (2) } \\
\text { Coarctation of the } \\
\text { aorta (1) } \\
\text { Ventricular septal } \\
\text { defect (1) }\end{array}$ & $\begin{array}{l}\text { Imperforate anus (2) } \\
\text { Tracheoesophageal } \\
\text { fistula with oesophageal } \\
\text { atresia (2) } \\
\text { Anorectal agenesis (2) } \\
\text { Duodenal atresia (1) } \\
\text { Exomphalos (1) } \\
\text { Annular pancreas (1) } \\
\text { Agenesis of gall- } \\
\text { bladder (1) }\end{array}$ & $\begin{array}{l}\text { Arnold-Chiari } \\
\text { malformation (1) } \\
\text { Meningo- } \\
\text { myelocoele (1) }\end{array}$ & Harelip (1) \\
\hline $\begin{array}{l}\text { Group } 2 \\
\text { (10 cases) }\end{array}$ & $\begin{array}{l}\text { Contralateral } \\
\text { hydronephrosis due to } \\
\text { ureteric stenosis (1) }\end{array}$ & & $\begin{array}{l}\text { Ventricular septal } \\
\text { defect (1) }\end{array}$ & $\begin{array}{l}\text { Tracheoesophageal } \\
\text { fistula with } \\
\text { oesophageal atresia (1) } \\
\text { Hiatus hernia (1) } \\
\text { Intrahepatic biliary } \\
\text { atresia (1) }\end{array}$ & & $\begin{array}{l}\text { Spina bifida } \\
\text { occulta (1) }\end{array}$ \\
\hline $\begin{array}{l}\text { Group } 3 \\
(22 \text { cases })\end{array}$ & $\begin{array}{l}\text { Unilateral renal } \\
\text { agenesis (1) }\end{array}$ & & & $\begin{array}{l}\text { Tracheoesophageal } \\
\text { fistula with oesophageal } \\
\text { atresia (1) } \\
\text { Rectal agenesis (1) }\end{array}$ & & $\begin{array}{l}\text { 'Prune belly' } \\
\text { syndrome (4) }\end{array}$ \\
\hline
\end{tabular}

Table III Associated congenital anomalies in the urogenital and other systems in the three groups of cases with renal dysplasia

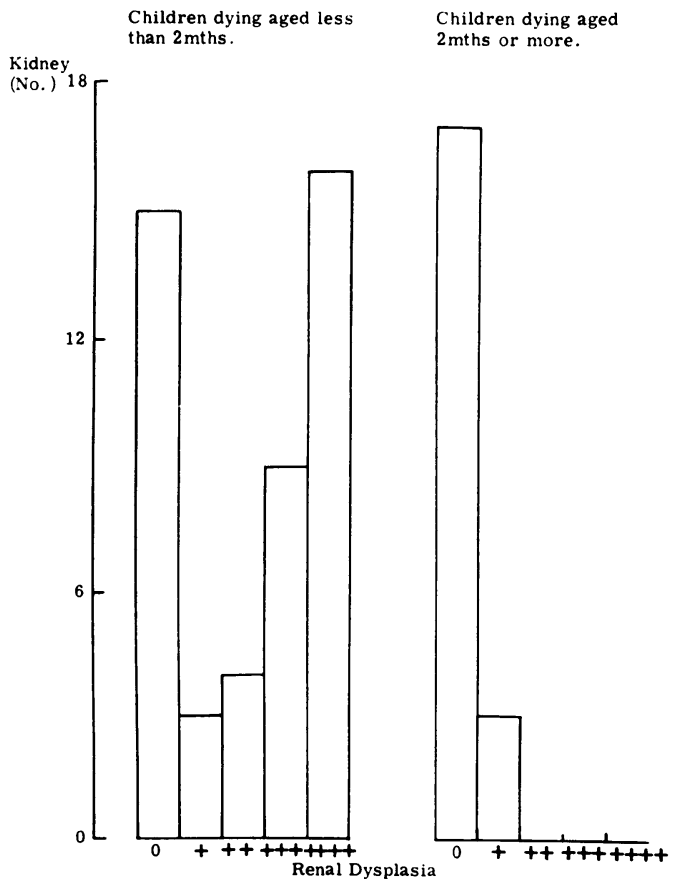

Fig. 5 Histological grading of the degree of renal dysplasia present in sections from each kidney in the 34 cases with congenital lower urinary tract obstruction correlated with the age at death. with histological evidence of pyelonephritis were aged 6 weeks or more at the time of death, whereas the seven cases in which pyelonephritis changes were absent were aged 19 days or less at death.

Of the 34 cases with bilateral hydronephrosis and hydroureters due to congenital lower urinary tract obstruction, histological evidence of renal dysplasia was present in $22(65 \%)$. Severe degrees of renal dysplasia $(++,+++$, or ++++$)$ were present only in those children dying in the first two months (Fig. 5).

\section{Discussion}

In the previous account of renal dysplasia in surgically resected kidneys in children (part I) the cases were divided into three main groups according to the pathological changes in the kidney and the associated anomalies in the draining urinary tract. Group 1 comprised cases of gross multicystic renal dysplasia associated with absence or atresia of the ureter and renal pelvis (Fig. 6). In group 2 renal dysplasia was segmental, and the draining ureter, whilst it possessed a lumen, showed some structural or functional abnormality which interfered with urinary drainage (Figs. 7 and 8). In group 3, renal dysplasia was associated with bilateral hydronephrosis and hydroureter due to lower 


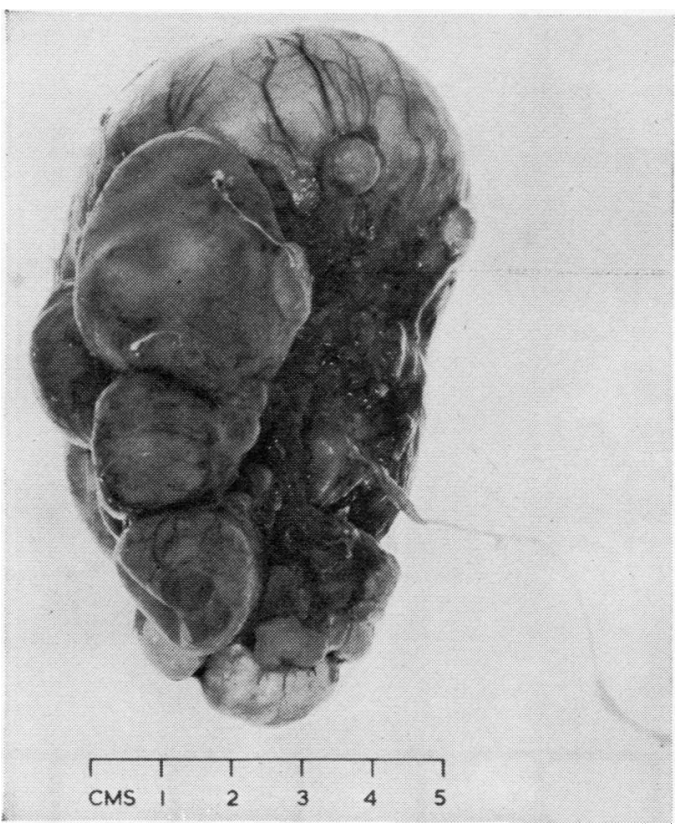

Fig. 6 Renal dysplasia (group 1). Gross multicystic renal dysplasia with atresia of the draining ureter.

urinary tract obstruction (Fig. 9). A similar grouping was used to classify the cases in the present survey of postmortem cases, and this emphasized important differences in the relative incidence of cases placed in the various groups in the two series. In two cases of unilateral multicystic dysplasia discovered at necropsy, the draining ureter, although grossly narrowed and hypoplastic, was not entirely atretic. These cases were included in group 1 because the changes in the kidney were entirely similar to the other cases in the group in that the cystic changes were gross and no normal renal parenchyma was discernible. Four cases included in group 3 in the postmortem series had congenital absence of the abdominal muscles, and were examples of the so-called 'prune belly' syndrome (McGovern and Marshall, 1959). All four had bilateral hydronephrosis and hydroureters and severe renal dysplasia. In three there was urethral obstruction due to urethral atresia or stenosis, but in the fourth case, although the posterior urethra was dilated, no definite mechanical obstruction was demonstrated. Inclusion of this case in group 3 seemed justified, since in all other respects the findings were indistinguishable.

Amongst the surgical cases, the numerically largest category were those in group 2 with 'duplex' kidneys in which the upper pole was dysplastic. Only one such case was present in the necropsy series. In the whole survey of postmortem cases there were 11 instances of 'double kidneys' with pelvic duplication, but in none of these was there any parenchymal dysplasia. It is of interest that in all of these the double ureters fused to form a single structure before insertion into the bladder, and the ureteric orifice was normally situated in the trigone. In contrast, 'duplex' kidneys with dysplasia of the upper pole invariably had two separate ureters draining the upper and lower poles. In every case fully investigated the ureter draining the dysplastic pole was inserted ectopically into the bladder, and in the majority of cases this was associated with a ureterocele (Berdon, Baker, Becker, and Uson, 1968).

Cases of congenitally small 'hypoplastic' dysplastic kidneys, and partially cystic dysplastic kidneys placed in group 2 , were slightly more common in the postmortem series. As in the surgical cases, structural abnormalities of the draining ureter were almost universal, being present in all but one case. The ureteric abnormalities were similar, and included ectopic insertion into the bladder, ureterocele, ureteric dilatation without obstruction, and ureteric hypoplasia.

In contrast to the surgical series in which all the cases placed in groups 1 and 2 had unilateral renal dysplasia, seven of the 19 postmortem cases in groups 1 and 2 showed bilateral involvement. In addition there were major congenital abnormalities in other systems in 10 instances. These anomalies, which are summarized in Table III, principally involved the cardiovascular and gastrointestinal systems, a finding also noted by Rubenstein, Meyer, and Bernstein (1961). These findings in groups 1 and 2 constituted the main difference between the surgical and necropsy series. Involvement of both kidneys or the presence of other major and often multiple congenital abnormalities were not compatible with survival.

In three of the cases placed in groups 1 and 2 in the necropsy series there was hydronephrosis of the contralateral kidney due to ureteric stenosis. In two the stenosis was at the pelviureteric junction and in the third the stenosis was at the junction of the upper and middle thirds of the ureter. Similar findings were present in two of the surgical cases. This type of abnormality in the opposite kidney is an important and not uncommon finding in cases of multicystic renal dysplasia, as has been emphasized by Pathak and Williams (1964). Early diagnosis of the contra- 


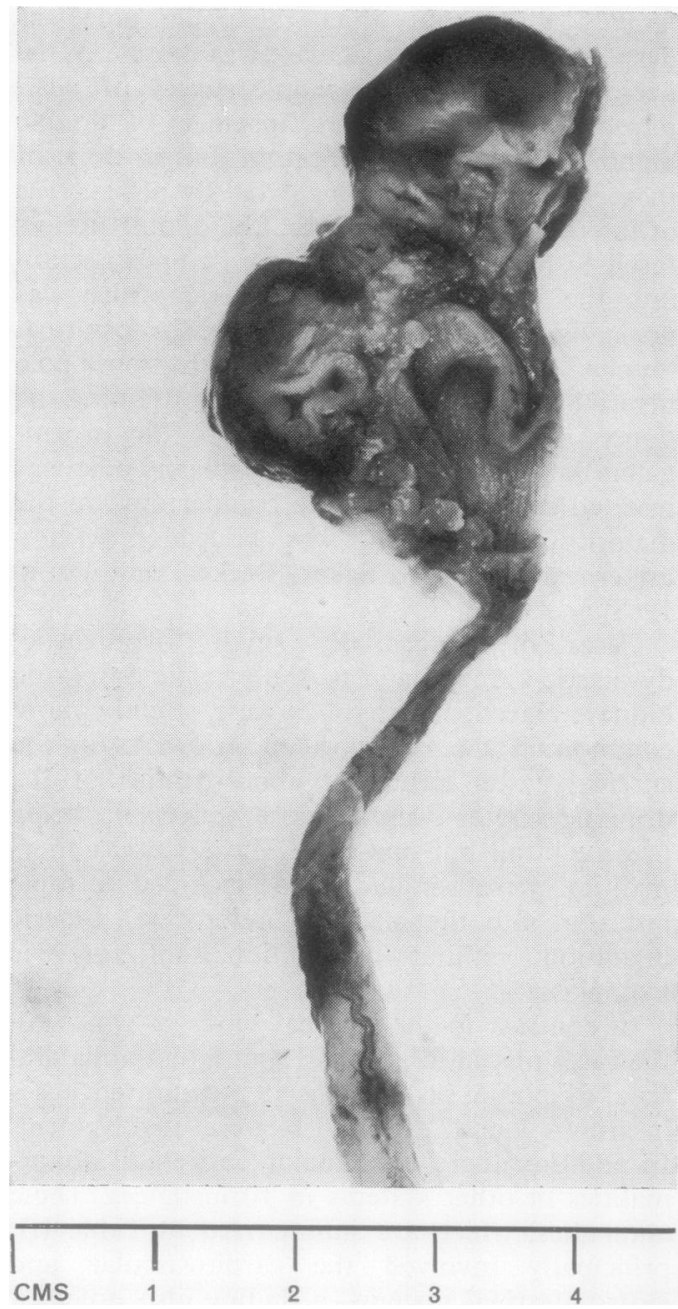

Fig. 7.

Fig. 7 Renal dysplasia (group 2). Congenitally small ('hypoplastic') kidney with a central dysplastic segment.

Fig. 8 Renal dysplasia (group 2). Partially cystic renal dysplasia. The cysts are separated by renal parenchymal tissue.

Fig. 9 Renal dysplasia (group 3). There is obstruction of the posterior urethra by valves and bilateral hydronephrosis and hydroureters. A 'stag horn' calculus is present on the left.

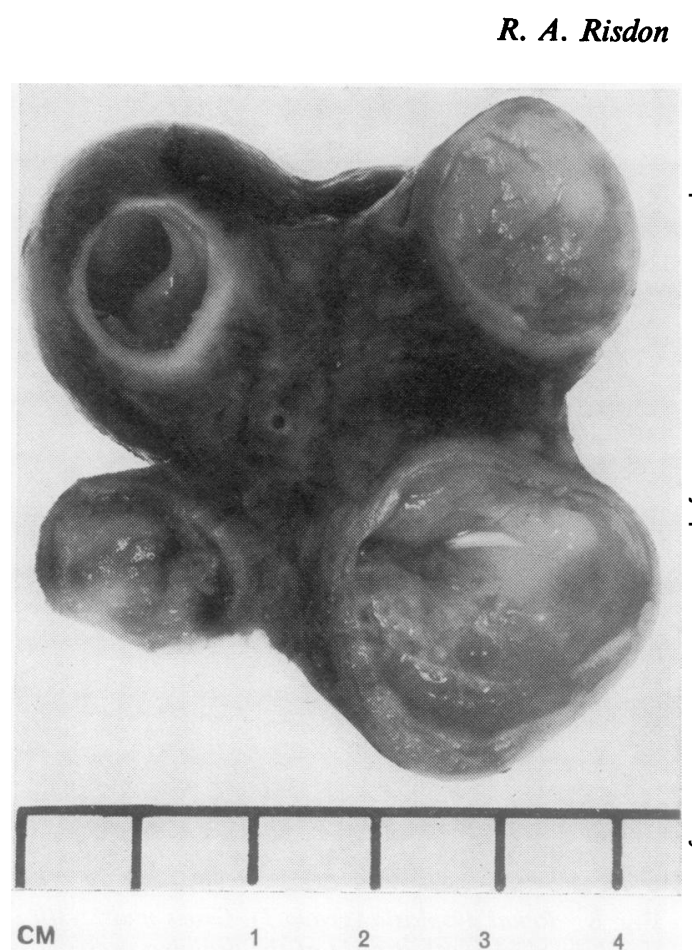

Fig. 8.

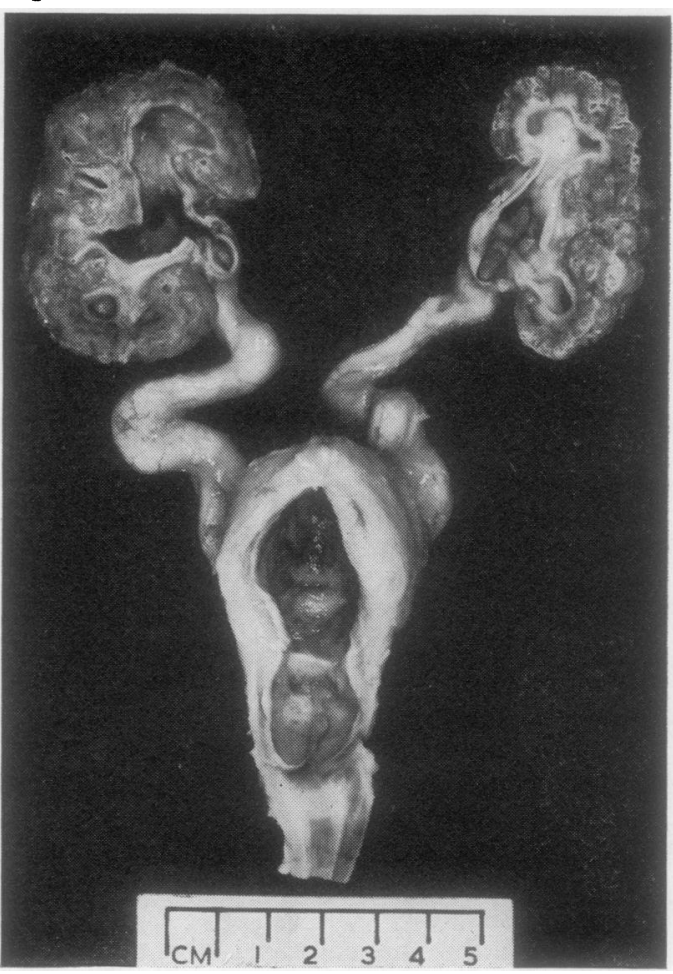

Fig. 9. 
lateral hydronephrosis is vital if progressive destruction by back-pressure and ascending infection is to be avoided in this single functional kidney.

The pattern of secondary pyelonephritis differed somewhat between the surgical and the necropsy series. None of the surgically resected dysplastic kidneys placed in group 1 showed histological evidence of pyelonephritis. Of the cases in group 1 found at necropsy, one case showed evidence of infection in the dysplastic kidney; scattered abscess formation and focal pyogenic inflammation were present. However, in this case infection was clearly blood-borne, since a pyonephrosis due to pelvi-ureteric obstruction was found in the opposite kidney. This was the only instance of infection in a multicystic dysplastic kidney in the 23 cases in both series in which the draining ureter was atretic or absent. This finding emphasizes the importance of ascending infection in the pathogenesis of pyelonephritis complicating renal dysplasia (Risdon, 1970). Histological evidence of pyelonephritis was less common in the cases in group 2 in the present series, only three of the 10 cases being affected, whereas all but one of the 45 surgical cases in this group showed pyelonephritic changes. This discrepancy probably reflects the difference in ages in the two series. The three cases in group 2 in the necropsy series were all aged 6 weeks or more at the time of death whereas the seven without pyelonephritic changes were aged 19 days or less. These seven cases all had either bilateral renal dysplasia or other major congenital abnormalities, these factors being responsible for their early death.

In all the cases found at necropsy to have bilateral hydronephrosis and hydroureters due to congenital lower urinary tract obstruction, including the cases of 'prune belly' syndrome, death had resulted from renal failure. This was variously due to a combination of pyelonephritis, renal atrophy due to hydronephrosis, and renal dysplasia. In order to assess the importance of renal dysplasia in this context, quantitative assessment was made in all cases of the degree of renal dysplasia in sections from both kidneys. Histological changes of renal dysplasia were found in $22(65 \%)$ of the 34 cases, and was bilateral in 16. This compares with an incidence of 10 out of 21 (eight bilateral) in a similar necropsy survey by Rattner et al (1963). Apart from the six cases in which only one kidney showed dysplastic changes, quantitative assessment showed that the degree of renal dysplasia present often varied in the two kidneys. In three instances severe renal dysplasia was present in one kidney and absent in the contralateral kidney. The occurrence of such marked variation in the degree of dysplasia in the two kidneys probably explains the much higher incidence of renal dysplasia in the surgical cases with congenital lower urinary tract obstruction, all but one of which were affected. In these, unilateral nephrectomy was performed to remove a non-functioning kidney. They were, therefore, highly selected in terms of disparate function on the two sides, and renal dysplasia might reasonably be expected to be commoner in the resected organ. Correlation of the age at death in the cases in this group coming to necropsy with the degree of renal dysplasia found in the kidneys showed that severe degrees of dysplasia were associated with early death, before the age of 2 months. Treatment of ascending infection and relief of the obstruction should not be expected to affect the outcome when both kidneys are severely deformed, but, as Rattner and his colleagues have emphasized, in other cases early diagnosis with surgical intervention and treatment of infection may be successful in preventing further progressive renal damage.

I should like to thank Professor A. E. Claireaux and Mr D. I. Williams for their helpful advice and criticism in the preparation of this paper. I am also indebted to Mr D. I. Williams for permission to use the clinical records of the cases studied.

\section{References}

Berdon, W. E., Baker, D. H., Becker, J. A., and Uson, A. C. (1968). Ectopic ureterocele. Radiol. Clin. N. Amer., 6, 205-214.

Coppridge, A. J., and Ratliff, R. K. (1958). Unilateral multicystic kidney disease. J. Pediat., 53, 330-335.

Ekström, T. (1955). Renal hypoplasia. A clinical study of 179 cases. Acta chir. scand., Suppl. 203.

Parkkulainen, K. V., Hjelt, L., and Sirola, K. (1959). Congenital multicystic dysplasia of the kidney. Report of nineteen cases with discussion on the etiology, nomenclature and classification of the cystic dysplasias of the kidney. Acta chir. scand., Suppl. 244.

Pathak, I. G., and Williams, D. I. (1964). Multicystic and cystic dysplastic kidneys. Brit. J. Urol., 36, 318-331.

Rattner, W. H., Meyer, R., and Bernstein, J. (1963). Congenital abnormalities of the urinary system. IV. Valvular obstruction of posterior urethra. J. Pediat., 63, 84-94.

Rubenstein, M., Meyer, R., and Bernstein, J. (1961). Congenital abnormalities of the urinary system. I. A postmortem survey of developmental anomalies and acquired congenital lesions in a children's hospital. J. Pediat., 58, 356-366.

McGovern, J. H., and Marshall, V. F. (1959). Congenital deficiency of the abdominal musculature and obstructive uropathy. Surg. Gynec. Obstet., 108, 289-305.

Vellios, F., and Garrett, R. A. (1961). Congenital unilateral multicystic disease of the kidney: a clinical and anatomic study of seven cases. Amer. J. clin. Path., 35, 244-254.

Spence, H. M. (1955). Congenital unilateral multicystic kidney: an entity to be distinguished from polycystic kidney disease and other cystic disorders. J. Urol., 74, 693-706. 